\title{
Trefoil factor family (TFF) proteins as potential serum biomarkers in patients with metastatic colorectal cancer
}

\author{
M. VOCKA ${ }^{1, *}$, D. LANGER ${ }^{2}$, J. PETRTYL ${ }^{3}$, P. VOCKOVA ${ }^{4}$, T. HANUS ${ }^{5}$, M. KALOUSOVA ${ }^{6}$, T. ZIMA ${ }^{6}$, L. PETRUZELKA ${ }^{1}$ \\ ${ }^{1}$ Department of Oncology, First Faculty of Medicine, Charles University, Prague, Czech Republic; ${ }^{2}$ Surgical Clinic, Second Faculty of Medicine, \\ Charles University, Prague, Czech Republic; ${ }^{3}$ Fourth Internal Clinic-Clinic of Gastroenterology and Hepatology, First Faculty of Medicine, Charles \\ University, Prague, Czech Republic; ${ }^{4}$ First Internal Clinic - Clinic of Hematology, First Faculty of Medicine, Charles University, Prague, Czech \\ Republic; ${ }^{5}$ Department of Urology, First Faculty of Medicine, Charles University, Prague, Czech Republic; ${ }^{6}$ Institute of Medical Biochemistry and \\ Laboratory Diagnostics, First Faculty of Medicine, Charles University, Prague, Czech Republic
}

${ }^{*}$ Correspondence: michal.vocka@vfn.cz

Received September 20, 2014 / Accepted November 19, 2014

\begin{abstract}
Trefoil factor family (TFF) is composed of three secretory proteins (TFF1, TFF2 and TFF3) that play an important role in mucosal protection of gastrointestinal tract. Their overexpression in colorectal tumors seems to be associated with more aggressive disease. We collected serum samples from 79 healthy controls and 97 patients with metastatic colorectal cancer at the time of diagnosis or at progression. Serum levels of TTF1-3, CEA and CA19-9 were measured by ELISA. Serum TFF1 and TFF3 levels were significantly higher in patients with colorectal cancer compared to healthy controls $(\mathrm{p}<0.0001)$. Moreover, serum levels of TFF3 correlated with extent of liver involvement in patient without pulmonary metastases and patients with higher TFF3 levels had significantly worse outcome ( $\mathrm{p}<0.0001)$. Compared to CEA and CA19-9, TFF3 had higher sensitivity and the same specificity. Our results indicate that TFF3 is an effective biomarker in patients with metastatic colorectal cancer with higher sensitivity than CEA a CA19-9. TFF3 levels strongly correlate with extension of liver disease and seem to have prognostic value.
\end{abstract}

Key words: colorectal cancer, TFF, TFF3, biomarker, survival

Colorectal cancer is the third most common cancer in men (746,000 cases, $10.0 \%$ of the total) and the second in women $(614,000$ cases, $9.2 \%$ of the total) worldwide [1]. Patient outcome strongly depends on the stage of tumor at the time of diagnosis [2]. Therefore, novel biomarkers for better cancer detection are needed.

Trefoil factor family (TFFs) is composed of three stable secretory proteins that are expressed together with mucins of the epithelial cells of gastrointestinal tract [3]. Members of the trefoil family are characterized by having at least one copy of the trefoil segment, a 40-amino acid domain that contains three conserved disulfide bonds [4]. The resistance of these peptides to proteolytic cleavage, acids and thermal degradation seems to be caused by the compact trefoil structure of the peptides $[5,6]$.

TFF1 is normally expressed in the gastroduodenal mucosa and loss of TFF1 expression has been observed in intestinal metaplasia of the incomplete type [7] and in gastric carcinomas [8]. TFF2 is produced by mucous neck cells in the body and in antral glands of the stomach, by superficial gastric foveolar cells and a small amount is expressed in Brunner's gland in the duodenum [9-11]. TFF3 is expressed in goblet cells of the intestine and also at lower levels in other organs such as breast, salivary gland, respiratory tract, and hypothalamus [10, 12-14].

The main role of TFFs is to promote epithelial restitution after injury. Discontinuation of mucosal surface leads to local increase of TFF expression. Expression of the other growth factors and signal pathways that work synergically with TFFs promote injury healing in gastrointestinal tract. Elevated expression of TFF3 has been found in reaction to mucosal injury by products of comensal bacteria via Toll-like receptor 2 (TLR2) [15-18]. TFFs enhance the protective characteristics of mucosal barrier in gastrointestinal tract and may also directly affect the package and secretion of mucin glycoproteins in the goblet cells [17-20]. TFF1 is essential for the normal differentiation of antral and pyloric mucosa, while TFF3 is needed for intestinal cell proliferation in development of gastrointestinal 
tract $[21,22]$. TFFs were also expressed in the brain (TFF1 in frontal cortex, cerebellum and hippocampus, whereas TFF3 in the hypothalamus) and they may act as neuromodulators [14,23-24]. TFF3 has malignant characteristics to promote the invasion of tumor cells by acting both directly on malignant cells and indirectly on the vasculature [25].

Serum levels of TFFs have been reported as biomarkers for several malignancies, mainly the gastric cancer [26-29,33].

In this study, we investigated the serum levels of TFFs in patients with metastatic colorectal cancer compared to the healthy controls. This is the first study that compares the levels of TFFs to standard biomarkers used in diagnosis and monitoring of colorectal cancer (CEA and CA19-9) with correlation studies of tumor characteristics and treatment outcomes to the serum levels of TFFs.

\section{Patients and methods}

Patients and healthy control characteristics. Between November 2011 and May 2013, 100 patients with metastatic $\mathrm{CRC}$ and 80 by the age- and gender matched healthy individuals were included in this study at the Department of Oncology of the First faculty of Medicine, Charles University and General Teaching Hospital in Prague. The serum samples from patients were collected at the time of distant metastasis diagnosis or in the time of progression validated by CT. The inclusion criteria were: histologically proven diagnosis of colorectal cancer; clinical stage IV; expected survival greater than six months; $>18$ years of age; adequate liver and renal function (transaminases $<2 \mathrm{x}$ and creatinine clearance $<1,5 \mathrm{x}$ upper normal limit) and signed informed consent. Serum samples from 58 patients were collected 3 months after the first one together with imaging control using RECIST 1.1 criteria. Healthy individuals signed informed consent, underwent healthy examination and had negative colonoscopy. Table 1 shows the backgrounds of the patients.

ELISA analysis. Serum samples collected from patients with colorectal cancer and healthy controls were stored at $-80^{\circ} \mathrm{C}$ until analysis. Concentrations of TFF- 1, TFF- 2 and TFF- 3 in serum samples were determined by commercially available colorimetric sandwich ELISA kits (Biovendor-Laboratorni medicina) according to the manufacturer's protocols. The sensitivity of the assays were $0.02 \mathrm{ng} / \mathrm{ml}$ (TFF-1), $0.05 \mathrm{ng} /$ $\mathrm{ml}$ (TFF-2) and $0.01 \mathrm{ng} / \mathrm{ml}$ (TFF-3) and intraassay or interassay coefficient of variation (CV) were always less than $10 \%$. Concentrations of CEA a CA 19-9 is serum samples were determined by commercially available chemoiluminiscent imnunoanalysis kits (Architect, Abbott, USA).

Statistical analysis. Statistical analysis was performed using SAS (SAS Institute Inc., Cary, NC, USA). Basic statistics were calculated for parameters measured in the whole group and in different groups and subgroups, such as mean, standard deviation, variance, median, interquartile range, minimum, maximum. Selected statistical data were also graphically processed, Box \& Whisker plot diagrams. Non-parametric analysis of variance two-sided Wilcoxon test was used for comparison of the distribution of the individual parameters in the different groups and subgroups. Due to non-gaussian distribution of variables Spearman's correlation coefficient was used to determine the dependency of characters. Statistical significance was determined at the border of alpha $=0.05$. Receiver operating characteristic (ROC) curves were generated to assess the diagnostic accuracy of each parameters, the sensitivity and specificity of optimum cut off point were found.

\section{Results}

Baseline characteristic of patients and controls. In the cancer group serum samples from 97 patients with generalized colorectal cancer were collected. The patient characteristics are shown in Table 1. There were included 60 (61.9\%) men and $37(38.1 \%)$ women with the median age 64.4 years (23.486.0 ). From 58 patients, we obtained the second serum sample 3 months after the first one.

The control group comprised serum samples from 79 healthy controls after negative colonoscopy. There were

Table 1. Basic characteristics of patients and healthy controls.

\begin{tabular}{|c|c|c|}
\hline & $\begin{array}{l}\text { cancer group } \\
(\mathrm{N}=97)\end{array}$ & $\begin{array}{l}\text { control group } \\
(\mathrm{N}=79)\end{array}$ \\
\hline \multicolumn{3}{|l|}{ age } \\
\hline - median & 64.4 & 61.5 \\
\hline$-<50$ & $13(13.4 \%)$ & $24(30.1 \%)$ \\
\hline$->50$ & $84(86.6 \%)$ & $55(69.6 \%)$ \\
\hline \multicolumn{3}{|l|}{ gender } \\
\hline - male & $60(61.9 \%)$ & $43(54.4 \%)$ \\
\hline - female & $37(38.1 \%)$ & $36(45.6 \%)$ \\
\hline \multicolumn{3}{|l|}{ histological type } \\
\hline - adenocarcinoma & $91(93.8 \%)$ & - \\
\hline - mucinous carcinoma & $6(6.2 \%)$ & - \\
\hline \multicolumn{3}{|l|}{ degree of differentiation } \\
\hline - well or moderate & $75(77.4 \%)$ & - \\
\hline - poorly & $21(21.6 \%)$ & - \\
\hline \multicolumn{3}{|l|}{ primary site } \\
\hline $\begin{array}{l}\text { - right colon } \\
\text { (caecum, ascendens, transversum) }\end{array}$ & $20(20.6 \%)$ & - \\
\hline $\begin{array}{l}\text { - left colon } \\
\text { (descendens, sigmoideum, rectosigma) }\end{array}$ & $50(51.5 \%)$ & - \\
\hline - rectum & $27(27.9 \%)$ & - \\
\hline \multicolumn{3}{|l|}{ side of metastasis } \\
\hline - liver & $64(66.0 \%)$ & - \\
\hline - lung & $31(32.0 \%)$ & - \\
\hline - peritoneal & $14(14.4 \%)$ & - \\
\hline - lymphatic nodules & $22(22.7 \%)$ & - \\
\hline \multicolumn{3}{|l|}{ number of metastatic sides } \\
\hline-1 & $57(58.7)$ & - \\
\hline-2 & $28(28.9)$ & - \\
\hline-3 or more & $12(12.4)$ & - \\
\hline \multicolumn{3}{|l|}{ number of previous treatment line } \\
\hline-0 & $52(53.6)$ & - \\
\hline-1 & $26(26.8)$ & - \\
\hline-2 & $19(19.6)$ & - \\
\hline
\end{tabular}


included $43(54.4 \%)$ men and $36(45.6 \%)$ women with the median age 61.5 years $(28.9-83.5)$.

Serum levels of TFFs. Serum level of TFF1 in the cancer group was significantly increased compared to healthy controls $(4.36+0.52 \mathrm{ng} / \mathrm{ml}$ and $1.83+0.15 \mathrm{ng} / \mathrm{ml}$, respectively, $p<$ 0.0001 , Figure $1 \mathrm{~A})$. In the control group there was no significant difference in TFF1 level between men and women $(\mathrm{p}=$ $0.461)$, but there was significant difference in younger than or equal to 55 years $(\mathrm{N}=24,1.00+0.13 \mathrm{ng} / \mathrm{ml})$ and older than $55(\mathrm{~N}=55 ; 2.19+0.20 \mathrm{ng} / \mathrm{ml} ; p=0.0003)$. Compared to the same aged group with colorectal cancer there were significant difference, $p=0.0041$ and 0.0031 , respectively.
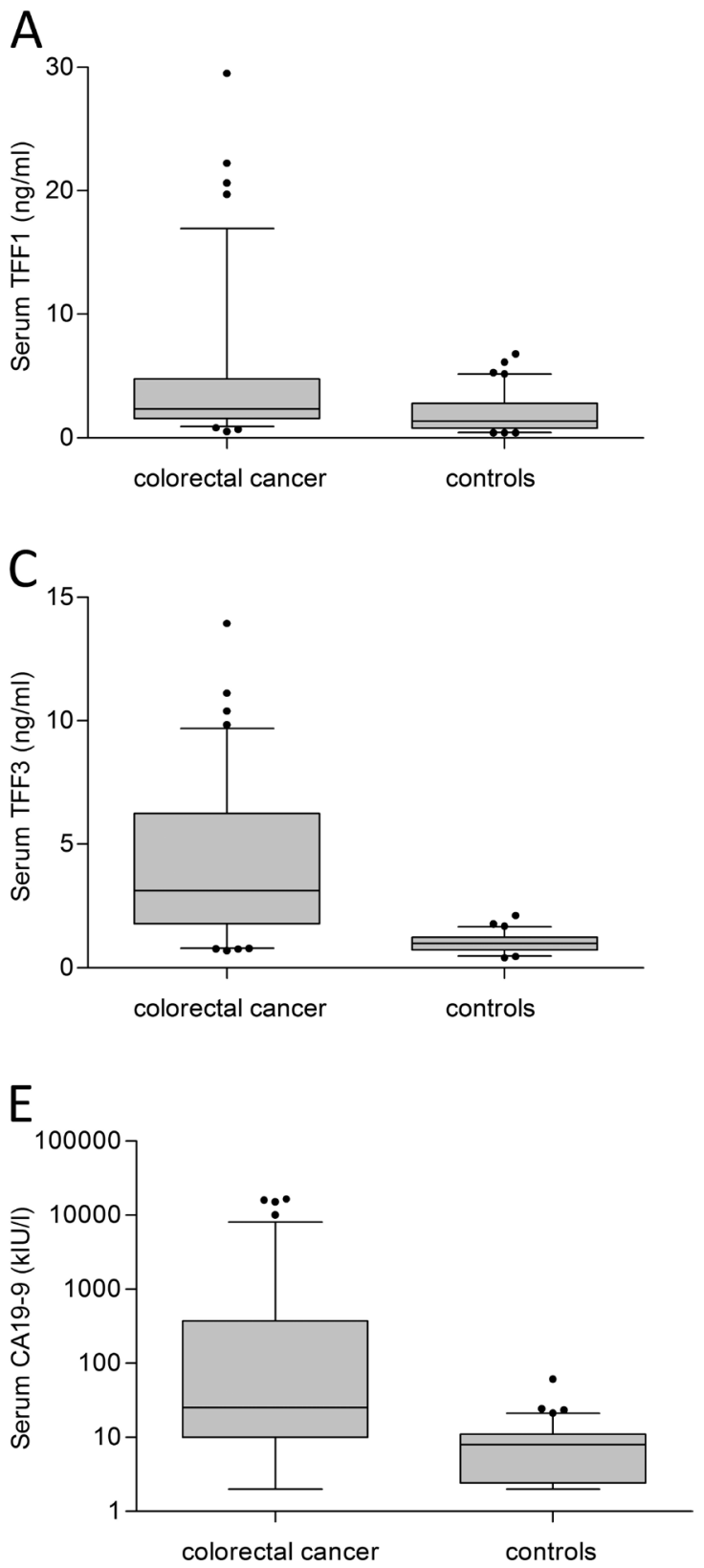

In the cancer group there was no significant difference in serum level of TFF1 between sex, age, site of colon with primary tumor, K-ras status and number of previous treatment line. Significant difference ( $p=0.0369$ ) was found between good or moderately and poorly differentiated tumors, $(\mathrm{N}=75) 3.81$ $+0.52 \mathrm{ng} / \mathrm{ml}$ vs $(\mathrm{N}=21) 6.47+1.51 \mathrm{ng} / \mathrm{l}$, respectively. Patients with non-resected primary tumor $(\mathrm{N}=20)$ had statistically significantly higher TFF1 levels $6.78+1.67 \mathrm{ng} / \mathrm{l}$ then patients after resection $(\mathrm{N}=77)$ with $3.73+0.48 \mathrm{ng} / \mathrm{l}(p=0.0178)$. No statistically significant difference between patients with liver metastases was found $(p=0.7216)$ and with distant lymphatic nodule metastasis $(\mathrm{p}=0.7262)$. Negative association was
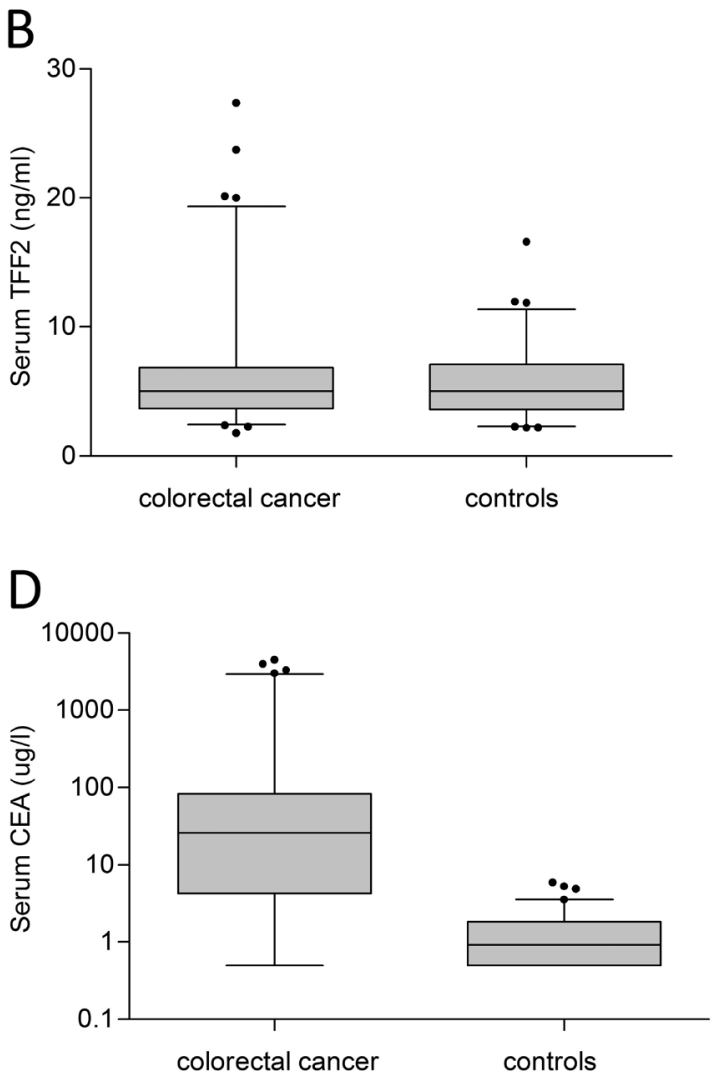

Figure 1. The comparison of TFF, CEA and CA19-9 levels in patients with colorectal cancer and healthy controls.

A - TFF1 levels $(p<0.0001)$, B - TFF2 levels $(p=0.1087)$, C - TFF3 levels $(p<0.0001)$, D - CEA levels $(p=0.0013), \mathrm{E}-\mathrm{CA19-9}(p=0.0064)$ 
indentified between patients with and without pulmonary metastases $(2.23+0.20 \mathrm{ng} / \mathrm{l}, \mathrm{N}=31 ; 5.36+0.73 \mathrm{ng} / \mathrm{ml}, \mathrm{N}=66$; $p=0.0047)$. In the group of patients without pulmonary metastasis $(\mathrm{N}=66)$ there was not identified any relevant difference between patients with $(\mathrm{N}=49)$ vs without $(\mathrm{N}=17)$ liver metastasis $(p=0.7699)$. There was indicated difference in pulmonary negative tumors with presence or absence of primary tumor, $7.30+1.94 \mathrm{ng} / \mathrm{ml}(\mathrm{N}=17)$ and $4.13+0.733 \mathrm{ng} / \mathrm{l}$ $(\mathrm{N}=36)$, respectively. But it was not statistically significant $(p$ $=0.0676$ ).

In the cancer group serum level of TFF2 was not significantly different from healthy controls, $6.59+0.50 \mathrm{ng} / \mathrm{ml} \mathrm{vs}$ $5.59+0.31 \mathrm{ng} / \mathrm{ml}$ respectively (Figure $1 \mathrm{~B}, p=0.1087$ ). In the control group there was no significant difference in TFF2 level between men and women $(p=0,686)$, but there was significant difference in younger than or equal to 55 years $(\mathrm{N}=24)$ and older than $55(\mathrm{~N}=55 ; p=0.0143)$. In the cancer group there was no significant difference in serum level of TFF2 between sex, age, part of colon with primary tumor, tumor grading, $\mathrm{K}$-ras status, number of previous treatment line, presence of primary tumor, liver and nodal metastases. Significant difference $(p=0.0129)$ was found between patients with $(\mathrm{N}=31)$ and without $(\mathrm{N}=66)$ pulmonary metastases, $4.79+0.34 \mathrm{ng} /$ $\mathrm{ml}$ and $7.43+0.69 \mathrm{ng} / \mathrm{ml}$ respectively $(p=0.0129)$.

Serum level of TFF3 in the cancer group was $4.19+0.30 \mathrm{ng} /$ $\mathrm{ml}$ and was significantly elevated compared to $1.03+0.04 \mathrm{ng} /$ $\mathrm{ml}$ in the healthy control group (Figure $1 \mathrm{C}, p<0.0001$ ). In the control group there was no significant difference in TFF3 level between men and women $(p=0.4040)$, but there was significant difference in younger than or equal to 55 years $(\mathrm{N}=24,0.83+0.07 \mathrm{ng} / \mathrm{ml})$ and older than $55(\mathrm{~N}=55 ; 1.12+$ $0.04 \mathrm{ng} / \mathrm{ml}, p=0.0005$ ). Copared to the same aged group with colorectal cancer there were significant difference, $p<0.0001$ and $<0.0001$, respectively.

In the cancer group there was no significant difference between sex, age, part of colon with primary tumor, tumor grade, K-ras status and number of previous treatment line. There was indicated difference in presence or absence of the primary tumor, $5.22+0.72 \mathrm{ng} / \mathrm{l}(\mathrm{N}=28)$ and $3.93+$ $0.33 \mathrm{ng} / \mathrm{l}(\mathrm{N}=69)$ respectively, but not statistically significant $(p=0.0864)$. If local recurrences were added to the group of non-resected primary tumor the difference between these and the group without colon or rectum involvement in the time of sample collection became statistically significant $(p=$ 0.0419 ). No statistically significant difference between patients with and without liver metastases was found $(p=0.1160)$ and with distant lymphatic nodule metastasis $(p=0.6397)$. Negative association was indentified between patients with and without pulmonary metastases $(2.93+0.35 \mathrm{ng} / \mathrm{l}, \mathrm{N}=31$; $4.79+0.40 \mathrm{ng} / \mathrm{ml}, \mathrm{N}=66 ; p=0.0038)$. In the group of patients without pulmonary metastasis $(\mathrm{N}=66)$ there was not identified any relevant difference between patients with $(\mathrm{N}=49)$ vs without $(\mathrm{N}=17)$ liver metastasis $(p=0.7699)$, although level of TFF3 was higher in patients with liver metastases. There was detected difference in pulmonary negative tumors with presence or absence of primary tumor, $7.30+1.94 \mathrm{ng} /$ $\mathrm{ml}(\mathrm{N}=17)$ and $4.13+0.733(\mathrm{~N}=36)$, respectively, but it was not statistically significant $(p=0.0676)$.

The group of patient with liver metastases without pulmonary metastases was divided into patients with the sum of the longest dimension of liver metastases smaller than 100 millimeters $(\mathrm{N}=20)$ and larger than or equal to 100 millimeters $(\mathrm{N}=29)$. The difference in TFF3 levels was statistically significant $(p<0.0001), 6.73+0.60 \mathrm{mg} / \mathrm{ml}$ and $2.36+0.29 \mathrm{mg} /$ $\mathrm{ml}$, respectively (Figure 2).

Serum levels of CEA and CA19-9. Serum level of CEA in the cancer group was $308.3+84.9 \mathrm{ug} / \mathrm{l}$ and was significantly elevated compared to $1.33+0.13 \mathrm{ug} / \mathrm{l}$ (Figure $1 \mathrm{D}, p=0.0013$ ). Serum level of CA19-9 in the cancer group was $948.1+307.0$ $\mathrm{kIU} / \mathrm{l}$ and was significantly elevated compared to $8.57+0.93$ $\mathrm{kIU} / \mathrm{l}$ in the control group (Figure $1 \mathrm{E}, p=0.0064$ ).

Sensitivity and specificity of TFF, CEA and CA19-9. ROC curves analysis showed that serum TFF1 with an AUC of 0.7222 (Figure $3 \mathrm{~A}$ ) and serum level cut-off $5.3 \mathrm{ng} / \mathrm{ml}$ has the sensitivity and specificity to distinguish colorectal cancer from healthy controls are $21.65 \%$ and $97.47 \%$, respectively $(p<0.0001)$. The TFF2 with AUC of 0.5211 (Figure 3B) and serum level cut-off values $>11.9 \mathrm{ng} / \mathrm{ml}$ has the sensitivity and specificity $13.40 \%$ and $97.47 \%$, respectively $(p=0.6310)$. The TFF-3 with AUC of 0.9164 (Figure 3C) and serum level cut-off values $>1.7 \mathrm{ng} / \mathrm{ml}$ has the sensitivity and specificity $76.29 \%$ and $97.47 \%$, respectively $(p<0.0001)$. The CEA with AUC of 0.9054 (Figure 3D) and serum level cut-off values $>5$ $\mathrm{ug} / \mathrm{l}$ has the sensitivity and specificity $72.16 \%$ and $97.47 \%$, respectively $(p<0.0001)$. The CA19-9 with AUC of 0.8023 (Figure 3E) and serum level cut-off values $>35 \mathrm{kIU} / \mathrm{l}$ has the sensitivity and specificity $46.39 \%$ and $96.25 \%$, respectively $(p<0.0001)$.

Change in levels of TFF3 during therapy. Serum samples from 60 patients were collected 3 months after first one together with imaging control using RECIST 1.1 criteria. The

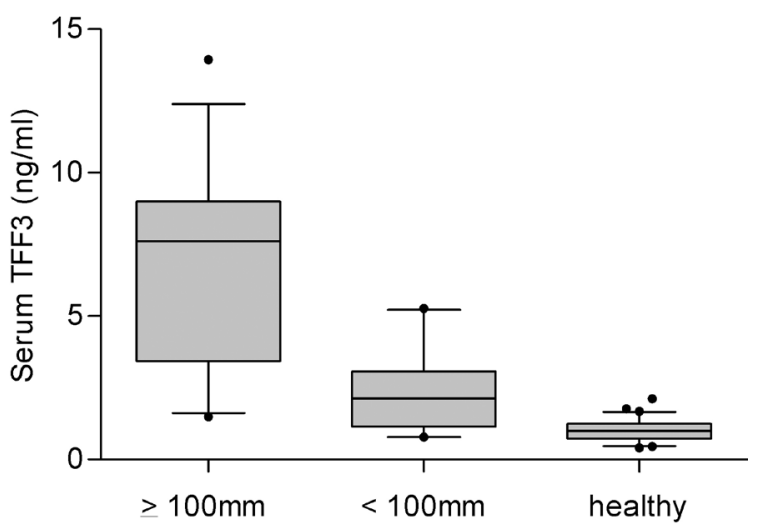

Figure 2. The serum levels of TFF3 in patients without pulmonary and with liver metastasis.

Liver metastaeses larger than or equal to $100 \mathrm{~mm}$, smaller than $100 \mathrm{~mm}$ and healthy controls. 
samples were divided into 3 groups according to imaging control (with partial remission, stable disease and progressing disease). In the group of patients with partial remission on CT scans $(\mathrm{N}=15)$ TFF3 levels decreased in nearly all patients (Figure $4 \mathrm{~A}$, mean difference was $-2.33 \mathrm{ng} / \mathrm{ml} ; \mathrm{p}=0.0023$ ). In the group of patients with stable disease on CT scans $(\mathrm{N}=$ 22) no statistically significant difference in TFF3 (Figure $4 \mathrm{~B}$, mean of difference is $0.09 \mathrm{ng} / \mathrm{ml} ; \mathrm{p}=0.9000$ ). In the last group with progression of disease on CT scans $(\mathrm{N}=21)$ TFF3 levels increased, but the difference was not statistically significant (Figure $4 \mathrm{C}$, mean of difference is $1.31 \mathrm{ng} / \mathrm{ml} ; \mathrm{p}=0.1003$ ).
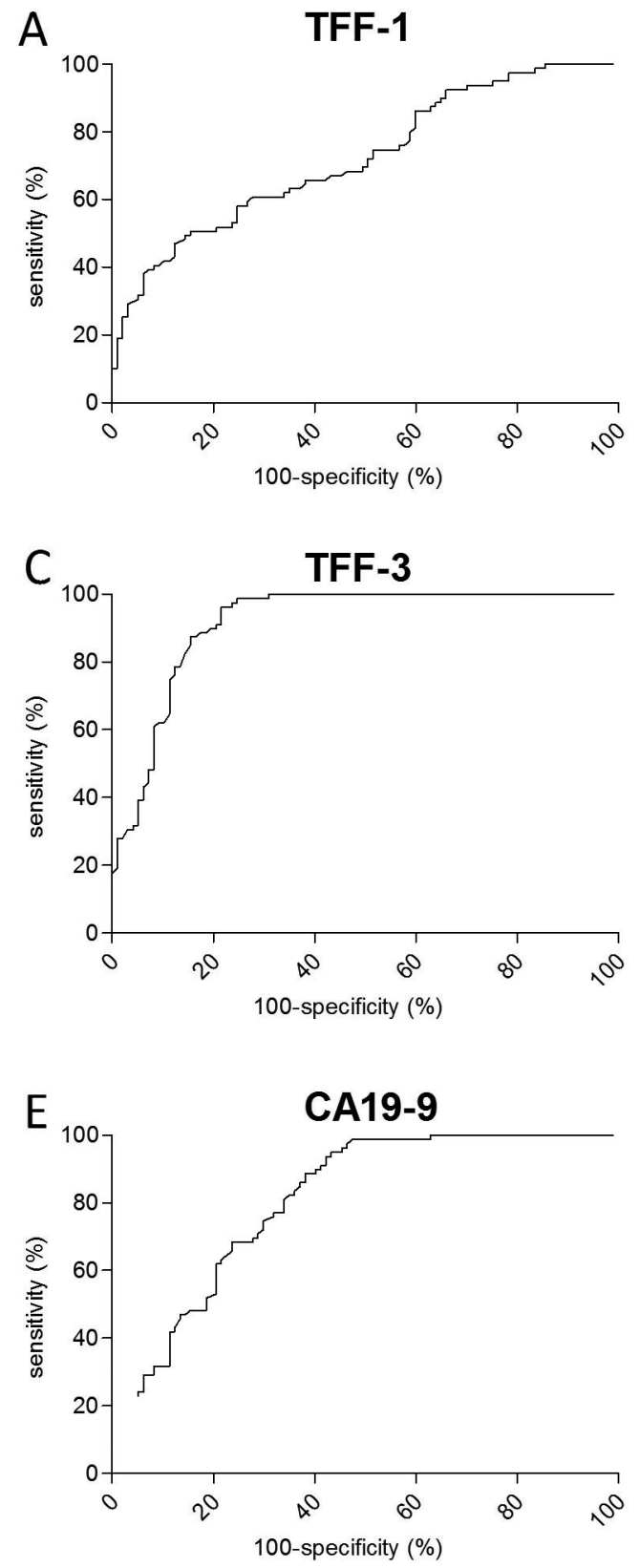

The level of TFF3 as prognostic factor. The serum level of TFF3 appears to have a prognostic value. The cut-off for serum TFF3 level was determined as $1.7 \mathrm{ng} / \mathrm{ml}$. Patients were divided into the group with negative serum levels of TFF3 $(<1.7 \mathrm{ng} /$ $\mathrm{ml}, \mathrm{N}=18$ ), slight increase ( $>1.7$ and $<3.4 \mathrm{ng} / \mathrm{ml}, \mathrm{N}=16)$ and large increase $(>3.4 \mathrm{ng} / \mathrm{ml}, \mathrm{N}=24)$. From all 58 patients overall survival (OS, time from first sample collection to death) was calculated. No significant difference $(p=0.2386)$ between group with negative TFF3 levels (mOS 17.87 months) and group with slight increase (mOS not reached) was observed. But there was statistically significant difference between these two groups (mOS 19.9 months) and the group with consider-
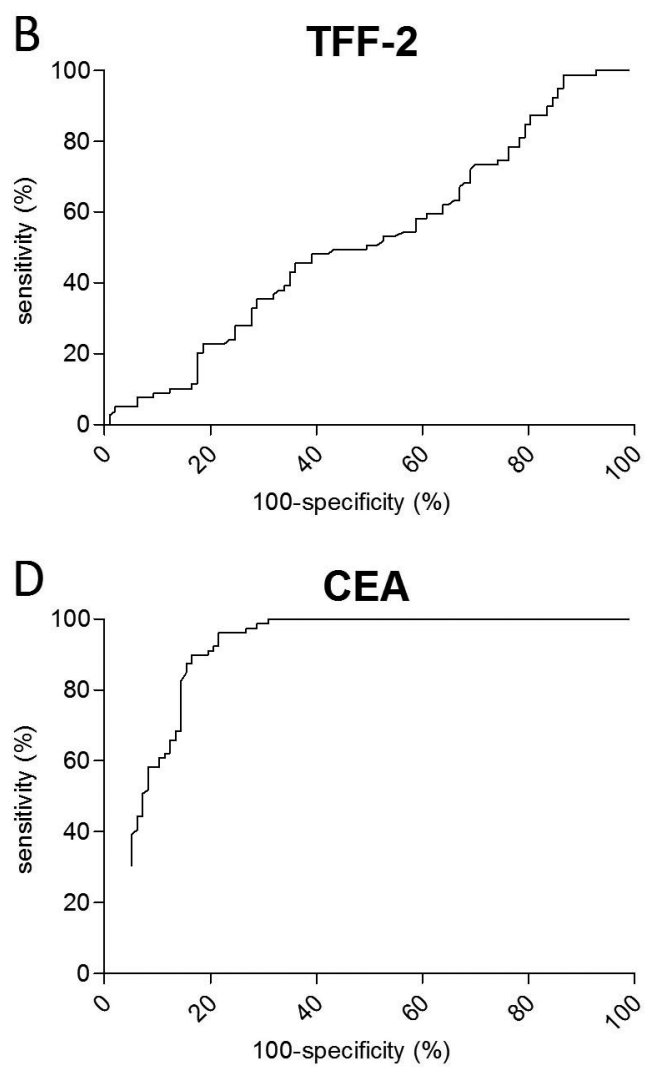

Figure 3. ROC curve analysis of TFFs, CEA and CA19-9.

A - TFF1 (AUC $=0.7222$ ) with serum level cut-off value $>5.3 \mathrm{ng} / \mathrm{ml}$, the sensitivity and specificity of TFF1 to distinguish colorectal cancer from healthy controls are $21.65 \%$ and $97.47 \%$, respectively $(p<0.0001)$. B - TFF2 (AUC $=0.5211)$ with serum level cut-off value $>11.9 \mathrm{ng} / \mathrm{ml}$, the sensitivity and specificity are $13.40 \%$ and $97.47 \%$, respectively $(p=0.6310)$. C - TFF3 (AUC $=0.9164$ ) with a serum level cut-off value $>1,7 \mathrm{ng} / \mathrm{ml}$, the sensitivity and specificity are $76.29 \%$ and $97.47 \%$, respectively $(p<0.0001)$. D - CEA $(A U C=0.9054)$ with serum level cut-off value $>5 \mathrm{ug} / \mathrm{l}$, the sensitivity and specificity are $72.16 \%$ and $97.47 \%$, respectively $(p<0.0001)$. E - CA19-9 (AUC $=0.8023)$ with serum level cut-off value $>35 \mathrm{kIU} / \mathrm{l}$, the sensitivity and specificity are $46.39 \%$ and $96.25 \%$, respectively $(p<0.0001)$. 
able increase of TFF3 serum level (mOS 7.8 months, $p<0.0001$; Figure 6). We tried the same with CEA and CA19-9, but there was no significant difference found.

\section{Discussion}

Colorectal cancer is one of the most common malignancies worldwide. [1] Early diagnosis is crucial for successful treatment whether they have only localized disease or distant metastases that could be resolved surgically. In patients with metachronous distant metastases previously treated for local disease early diagnosis is important for possible radical resection. Therefore, new biological markers for early detection (more sensitive and specific than CEA and CA19-9) and predictors of prognosis for colorectal cancer are urgently needed in clinical practice.

TFFs as secreted proteins play an important role in cell signaling, communication and migration. [30,31] TFF3 has malignant characteristics to promote the invasion of tumor cells by acting both directly on malignant cells and indirectly on the vasculature [27]. Several earlier clinical studies identified serum TFF3 as a new marker for gastric cancer. $[32,33]$ In one study TFF3 levels in urine and serum were examined in patients with colorectal cancer and gastric cancer. The serum levels correlated with TNM stage and response to therapy, but the comparison with standard tumor markers (CEA and CA19-9) was not investigated. [34]

We found that serum TFF1 levels are significantly different between the patients and healthy controls. The TFF1 levels are higher in patients with poor differentiated tumors, patients with colon or rectum involvement (non-resected primary tumor or local recurrence), and between patient younger than or equal to 55 years and older than 55 . Despite of these promising and interesting data TFF1 has not better sensitivity for the disease detection than CEA and CA19-9. Also the serum levels of TFF 2 in the cancer group were not significantly elevated compared to the healthy controls.

The TFF3 levels were significantly higher in patients compared to controls. Serum levels of TFF3 correlated with the extent of colon or rectum involvement (non-resected primary tumor or local recurrence), and also with the extent of liver involvement in cases without pulmonary metastases. This finding is very interesting because these patients could be candidates for a radical resection of liver metastases, the only modality that can cure them completely.

The TFF3 has better sensitivity than CEA with the same specificity and its level correlate with tumor response controlled by CT scans (RECIST 1.1) better than CEA and CA19-9. These results suggested that serum TFF3 may be a potential useful biomarker and a pharmacodynamic marker of response to chemotherapy.

The entry level of TFF3 appears to be a prognostic factor that strongly correlates with overall survival. This can be partially explained by strong correlation of TFF3 level with liver involvement in patient without pulmonary metastases.
Patients with amount of liver metastases larger than $100 \mathrm{~mm}$ had significantly higher levels of TFF3 and their liver reserve is smaller. Another partial explanation could be, that patients with non-resected primary tumor, who have higher levels of TFF3, were not surgically treated because of their worse performance status and that may be the reason for a worse outcome of the treatment. Further investigation and data are needed to clarify these results.
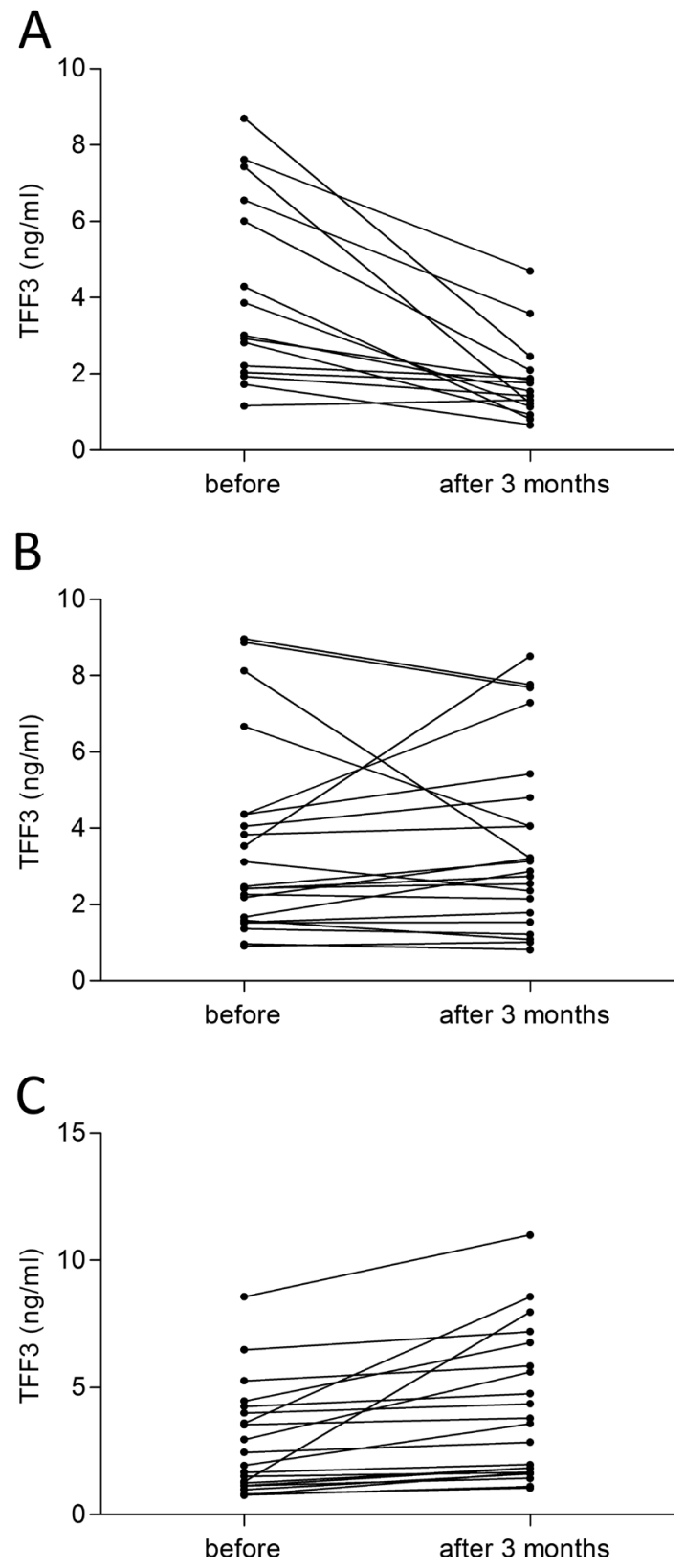

Figure 4. Change of TFF3 levels after 3 months of therapy. A - Partial remission according to CT scans (RECIST 1.1) B - Stable disease according to CT scans (RECIST 1.1) C - Progression according to CT scans (RECIST 1.1) 


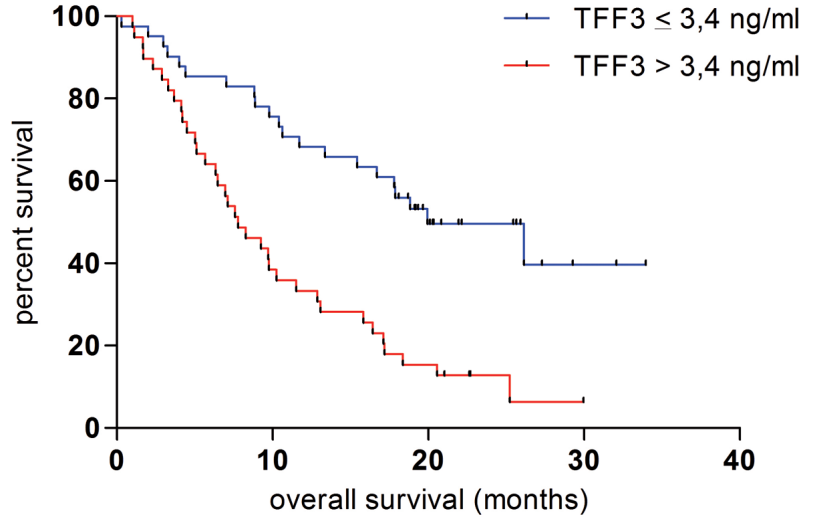

Figure 5. Overall survival according to TFF3 levels.

Kaplan-Meier curves of pacients with TFF3 level $<3.4 \mathrm{ng} / \mathrm{ml}$ (mOS 19.9 months) compared to pacients with TFF3 level $>3.4 \mathrm{ng} / \mathrm{ml}(\mathrm{mOS} 7.8$ months, $p<\mathbf{0 . 0 0 0 1 )}$.

\section{Summary}

Our data indicated that serum TFF3 can be used as an effective biomarker for the detection of distant metastasis more sensitive than CEA and CA19-9 and as a pharamacodynamic marker of a response to chemotherapy in gastrointestinal cancer. TFF3 may play an important role in detecting colorectal cancer progression and dissemination. Our data have shown that decreased serum TFF3 levels significantly correlate with response to chemotherapy in the group of patient with partial regression and not significantly correlated with the group having disease progression. TFF3 strongly correlates with extension of liver involvement in patients without pulmonary metastases, who are the candidates for a curative liver resection. The entry level of TFF3 appears to be prognostic factor that strongly correlates with overall survival.

\section{References}

[1] FERLAY J, SHIN HR, BRAY F, FORMAN D, MATHERS C Estimates of worldwide burden of cancer in 2008: GLOBOCAN 2008. Int J Cancer. 2010; 127: 2893-2917. http://dx.doi. org/10.1002/ijc.25516

[2] O`CONNELL JB, MAGGARD MA, KO CY Colon cancer survival rates with the new American Joint Committee on Cancer sixth edition staging. J Natl Cancer Inst. 2004; 96(19): 1420-5. http://dx.doi.org/10.1093/jnci/djh275

[3] WRIGHT NA, POULSOM R, STAMP G, VAN NOORDEN S, SARRAF C, et al. Trefoil peptide gene expression in gastrointestinal epithelial cells in inflammatory bowel disease. Gastroenterology 1993; 104: 12-20.

[4] THIM L A new family of growth factor-like peptides. ,Trefoil disulphide loop structures as a common feature in breast cancer associated peptide (pS2), pancreatic spasmolytic polypeptide (PSP), and frog skin peptides (spasmolysins). FEBS Lett. 1989; 250: 85-90. http://dx.doi.org/10.1016/00145793(89)80690-8

[5] THIM L, WOLDIKE HF, NIELSEN PF, CHRISTENSEN M, LYNCH-DEVANEY K et al. Characterization of human and rat intestinal trefoil factor produced in yeast. Biochemistry. 1995; 34: 4757-4764. http://dx.doi.org/10.1021/bi00014a033

[6] JORGENSEN KH, THIM L, JACOBSEN HE Pancreatic spasmolytic polypeptide (PSP): I. Preparation and initial chemical characterization of a new polypeptide from porcine pancreas. Regul Pept. 1982; 3: 207-219. http://dx.doi.org/10.1016/01670115(82)90126-4

[7] WU MS, SHUN CT, WANG HP, LEE WJ, WANG TH et al. Loss of pS2 protein expression is an early event of intestinaltype gastric cancer. Jpn J Cancer Res. 1998; 89: 278. http:// dx.doi.org/10.1111/j.1349-7006.1998.tb00559.x

[8] LEUNG WK, YU J, CHAN FK, TO KF, CHAN MW et al. Expression of trefoil peptides (TFF1, TFF2, and TFF3) in gastric carcinomas, intestinal metaplasia, and non-neoplastic gastric tissues. J Pathol. 2002; 197: 582. http://dx.doi.org/10.1002/ path. 1147

[9] HAUSER F, POULSOM R, CHINERY R, ROGERS LA, HANBY AM et al. hP1.B, a human P-domain peptide homologous with rat intestinal trefoil factor, is expressed also in the ulcer-associated cell lineage and the uterus. Proc Natl Acad Sci. 1993; 90: 6961-6965. http: //dx.doi.org/

[10] PODOLSKY DK, LYNCH-DEVANEY K, STOW JL, OATES P, MURGUE B et al. Identification of human intestinal trefoil factor. Goblet cell-specific expression of a peptide targeted for apical secretion. J Biol Chem. 1993; 268: 6694-6702.

[11] MADSEN J, NIELSEN O, TORNOE I, THIM L, HOLMSKOV U Tissue localization of human trefoil factors 1,2 , and 3. J Histochem Cytochem. 2007; 55: 505-513. http://dx.doi. org/10.1369/jhc.6A7100.2007

[12] POULSOM R, HANBY AM, LALANI EN, HAUSER F, HOFFMANN $W$ et al. Intestinal trefoil factor (TFF 3) and pS2 (TFF 1), but not spasmolytic polypeptide (TFF 2) mRNAs are co-expressed in normal, hyperplastic, and neoplastic human breast epithelium. J Pathol. 1997; 14: 30-38. http:// dx.doi.org/10.1002/(SICI)1096-9896(199709)183:1<30::AIDPATH1085>3.0.CO;2-K

[13] DEVINE DA, HIGH AS, OWEN PJ, POULSOM R, BONASS WA Trefoil factor expression in normal and diseased human salivary glands. Hum Pathol. 2000; 14: 509-515. http://dx.doi. org/10.1053/hp.2000.6549

[14] JAGLA W, WIEDE A, DIETZMANN K, RUTKOWSKI K, HOFFMANN W Co-localization of TFF3 peptide and oxytocin in the human hypothalamus. FASEB J. 2000; 14: 1126-1131.

[15] SANDS BE, PODOLSKY DK The trefoil peptide family. Annu Rev Physiol. 1996; 58: 253-73. http://dx.doi. org/10.1146/annurev.ph.58.030196.001345

[16] THIM L Trefoil peptides: from structure to function. Cell Mol Life Sci. 1997; 53): 888-903.

[17] PODOLSKY DK Mechanisms of regulatory peptide action in the gastrointestinal tract: trefoil peptides. J Gastroenterol. 2000; 35(12): 69-74. 
[18] TAUPIN D, PODOLSKY DK Trefoil factors: initiators of mucosal healing. Nat Rev Mol Cell Biol. 2003; 4(9): 721-32. http://dx.doi.org/10.1038/nrm1203

[19] HOFFMANN W, JAGLA W, WIEDE A Molecular medicine of TFF-peptides: from gut to brain. Histol Histopathol. 2001; 16: 319-34.

[20] KINDON H, POTHOULAKIS C, THIM L, LYNCHDEVANEY K, PODOLSKY DK Trefoil peptide protection of intestinal epithelial barrier function: cooperative interaction with mucin glycoprotein. Gastroenterology 1995; 109: 516-23. http://dx.doi.org/10.1016/0016-5085(95)90340-2

[21] LEFEBVRE O, CHENARD MP, MASSON R, LINARES J, DIERICH A at al. Gastric mucosa abnormalities and tumorigenesis in mice lacking the pS2 trefoil protein. Science. 1996; 274: 259-62. http://dx.doi.org/10.1126/ science.274.5285.259

[22] MASHIMO H, WU DC, PODOLSKY DK, FISHMAN MC Impaired defense of intestinal mucosa in mice lacking intestinal trefoil factor. Science. 1996; 274: 262-5. http://dx.doi. org/10.1126/science.274.5285.262

[23] PROBST JC, ZETZSCHE T, WEBER M, THEILEMANN P, SKUTELLA T et al. Human intestinal trefoil factor is expressed in human hypothalamus and pituitary: evidence for a novel neuropeptide. FASEB J. 1996; 10: 1518-23.

[24] HIROTA M, AWATSUJI H, SUGIHARA Y, MIYASHITA S, FURUKAWA Y et al. Expression of pS2 gene in rat brain. Biochem Mol Biol Int. 1995, 35: 1079-1084.

[25] MAY FE The potential of trefoil proteins as biomarkers in human cancer. Biomark Med. 2012; 14: 301-304. http://dx.doi. org $/ 10.2217 / \mathrm{bmm} .12 .22$

[26] QU Y, YANG Y, MA D, XIAO W Increased trefoil factor 3 levels in the serum of patients with three major histological subtypes of lung cancer. Oncol Rep. 2012; 14: 1277-1283. http://dx.doi.org/10.3892/or.2012.1627
[27] BIGNOTTI E, RAVAGGI A, TASSI RA, CALZA S, ROSSI E ET AL. Trefoil factor 3: a novel serum marker identified by gene expression profiling in high-grade endometrial carcinomas. Br J Cancer. 2008; 14: 768-773. http://dx.doi. org/10.1038/sj.bjc. 6604546

[28] LACROIX M Significance, detection and markers of disseminated breast cancer cells. Endocr Relat Cancer.2006; 14: 1033-1067.

[29] WALKER G, MACLEOD K, WILLIAMS AR, CAMERON DA, SMYTH JF et al. Estrogen-regulated gene expression predicts response to endocrine therapy in patients with ovarian cancer.Gynecol Oncol. 2007; 14: 461-468. http://dx.doi. org/10.1016/j.ygyno.2007.05.009

[30] MAY M From cells, secrets of the secretome leak out. Nat Med. 2009; 14: 828. http: //dx.doi.org/10.1038/nm0809-828 http://dx.doi.org/10.1038/nm0809-828

[31] KULASINGAM V, DIAMANDIS EP Strategies for discovering novel cancer biomarkers through utilization of emerging technologies. Nat Clin Pract Oncol. 2008; 14: 588-599. http:// dx.doi.org/10.1038/ncponc1187

[32] AIKOU S, OHMOTO Y, GUNJI T, MATSUHASHI N, OHTSU $\mathrm{H}$ et al. Tests for serum levels of trefoil factor family proteins can improve gastric cancer screening. Gastroenterology 2011; 14: 837-845. http://dx.doi.org/10.1053/j.gastro.2011.05.040

[33] KAISE M, MIWA J, TASHIRO J, OHMOTO Y, MORIMOTO $S$ et al. The combination of serum trefoil factor 3 and pepsinogen testing is a valid non-endoscopic biomarker for predicting the presence of gastric cancer: a new marker for gastric cancer risk. J Gastroenterol. 2011; 14: 736-745. http:// dx.doi.org/10.1186/1471-230X-14-74

[34] XIAO L, LIU YP, XIAO CX, REN JL, GULENG B Serum TFF3 may be a pharamcodynamic marker of responses to chemotherapy in gastrointestinal cancers. BMC Clin Pathol. 2014; 14: 26. http://dx.doi.org/10.1186/1472-6890-14-26 